\title{
Re-defining wall painting of the Yoruba of south-west Nigeria for cultural tourism
}

\author{
P. S. O. Aremu ${ }^{1}$, N. Umoru-Oke ${ }^{1}$, E. Tolulope Ijisakin ${ }^{1}$ \\ \& B. Banjo ${ }^{2}$ \\ ${ }^{I}$ Department of Fine and Applied Arts, Obafemi Awolowo University, \\ Nigeria \\ ${ }^{2}$ Tai Solarin Department of Creative Arts, University of Education, \\ Nigeria
}

\begin{abstract}
The religion of the traditionalists in this area of the country gave birth to the art of shrine painting. They make use of concrete elements such as images, colours, patterns and symbols in the religious beautification of the shrines meant to house the spirits, deities and the ancestors. Custodians and knowledgeable people as well as the adherents of various traditional religions were interviewed to compare their submissions regarding paintings used to meet the feelings of confidence and assurance of the deities. The shrine paintings in Yoruba speaking areas conform to certain universal pattern elements in the act of honouring, soothing and cooling the gods and likewise influence their decisions to favour man in his incessant struggle on earth. It is worthy of note to add that both the painters and their clients (worshippers) have to spiritually contribute to the iconographic and aesthetic features of the painting. These eventually reflect in worship value, which draws the worshippers closer to their deities that are deemed to have their comfort in the decorated shrines. For this reason, there is an urgent need to document this aspect of Yoruba conceptual association with the universe. Lastly, the goal of this paper is to highlight and to bring to the fore the salient, cultural values embedded in Yoruba shrine painting. In a like vein, this paper intends to serve an aspect of the most radiant cultural atmosphere in human religious history, thereby proclaiming it as a veritable source for tourism in the study areas.
\end{abstract}

Keywords: shrine, painting, cultural, worshippers, religion, deities, iconography. 


\section{Introduction}

The paper aims at highlighting how the tourism product may contribute to the cultural and economic development of the area. During the course of fieldwork it was discovered that shrine painting is used to meet that aspect of universal belief that, according to [1]; the whole organization of society is maintained by the spiritual forces that pervade it. The shrine is the abode of the spirits and the spiritual power is harnessed therein to purify and cleanse the society of malevolent forces.

To most Yoruba, life has no value of its own if the presence and power of the ancestral spirit and that of the mythical are excluded. The ancestral spirits are part of the family and are consulted frequently, sometimes in shrines, to see to their activities in the physical world of man Ode-aye [2]. It is also believed that each divinity has a role to play in the governmental set-up of life in Yoruba communities. Due to this belief, the people create shrines through which these deities could be pacified, worshipped and equally bring people together in a healthy and joyous cohesion, [3] submits that there are so many possible objects and forces which may be associated with the spirits of the earth. Some are seen as more important than others in the lives of those who believe in them. This is why we have various shrines with specific deity in charge. Religious ceremonies and festivals are always carried out in these shrines, which are decorated with symbols, patterns, images and religious colours. These motifs and colours have their original meanings they bring into the world of man.

In some communities in Yorubaland, these shrine painters are free to initiate or copy from the abundant traditional pots of creativity, unlike in some communities in Black Africa where art is generally controlled by the kingship, whereby artist has no choice but to listen to the dictates of what and how to do certain art work. He has no right to even imitate any original or individual concept, thought or even theme. Among the Bamileke tribe of Mali for example, artists were considered as royal slaves whose works were the properties of the kings or chiefs who claim the credit of the art works. In the past, among the Edo people, artists who worked with bronze to produce art works used by the king belonged to a guild under a chief who held the status of a priest and acted as the intermediary between the artists and the king, Oba. These artists were placed higher than ordinary people in the society. Among the Kalabari of South-eastern part of Nigeria likewise, artists have no reward for imagination, their art works must include certain symbols, patterns and natural features before they are accepted. The above therefore express the restrictions imposed on traditional African artists who seem to have their art works reduced to mere crafts.

Among the Yoruba shrine painters, the restrictions are mainly between them and the deities they tend to satisfy. It was discovered that this art-style has its own guiding principles. Basically, these principles are guided by mystical order governing the whole universe, of which traditional religions are the basic. Shrine painting is therefore a reflection of traditional societies and cannot be separated from their religious life. 


\section{Study area}

Despite the great external influences that affect many aspects of black societies the world over, the Yoruba people of the south-western part of Nigeria still show their traditional artistry in shrine painting. Shrine painting is seen where traditional religious beliefs thrive; this includes nearly all the ethnic groups in the area of study. Areas such as Ile-Ife (the cradle of Yoruba race), Ogbomoso, Oyo, Osogbo, Ikirun, Ibadan, Ikire and many other towns and villages where traditional religions are still strongly adhered to.

\section{Methodology}

The methodology of this study includes primary and secondary sources of data collection. The primary sources involved visiting women shrine painters in their respective shrines for personal interviews and visual examination of the art works on the walls. The shrine painters were randomly selected from the area of study. Interactions inform of questions and answers took place to evoke responses on certain questions posed to them. The question embraced the reason why most of the painters are aged between 60 years and 65 years. This has greatly helped to substantiate the oral submissions collected from various sources. The facts collected were later compared and interpreted so as to ascertain their validity. The secondary sources involved consultation of books, journals and catalogues.

\section{Research finding}

The study discovers that shrine paintings as found in Yorubaland serve as a vehicle with which nature-spirit is linked with. The spirits that sojourn in these shrines, according to [3] can do both good and evil to the society, just as people do both good and evil to their fellow human beings.

In these shrines are ritual objects, such as drums used in ceremonies, carved images, mud sculptured pieces, sacred stools used by the chief priests and other religious treasures of which are cowries and paintings on walls. All these items are used during annual or occasional festivals to solicit favours from the ancestral spirits in the society. It was also discovered that the Yoruba shrine painters, in an attempt to solve the problem of man in his physical and supernatural world, select symbols, patterns, images and colour scheme, which best reflect their cosmology to create a feeling of security and cohesion in the face of inevitable danger and doubt in their society. There seems to be some parallelism in the development, but the similarities seem to be greater than the differences in the execution and use of motifs and colour symbolism. The study then concludes that culture as well as economic values of the shrine could be seriously and profitably achieved if more attention in form of funding is drawn towards its survival. 


\section{Shrine painting in traditional Yoruba society}

Origin of wall painting could be traced to the pre-historic period when man roamed the forest and later settled down in caves and decorated his dwelling with patterns and images. The early man painted both man and animal figures whose postures and movements had been studied critically. These figures showed that they were not for mere naturalistic reproductions, but made to serve certain crucial purposes in their lives; the same reason that goes for shrine paintings of the Yoruba. It was used as a form of ritual art, as it is for the present Yoruba people and other people in black African countries. Hence, the first interplay of religion and art in the history of mankind.

According to Yoruba cosmology, 'Obatala' the arch-divinity is believed to be the first artist and the originator of shrine painting. He does not allow realistic representations of man and animal; hence, the abstraction and linear representation of images in all spheres of ritual art of the Yoruba people [7].

Shrine painting can not be entirely separated from the Yoruba traditional religions and the society. To this end therefore, an attempt will be made to stimulate a critical examination of certain concepts that are part of the most basic ideological currency in Yoruba traditional society. These concepts are the specific reasons why the paintings exist at all; some of which are the basic reason for survival in life and the total wellbeing of man and his activities.

Ultimately, the goal of this section is to elucidate the everyday understandings of the paintings as they relate to human submissions to the experiences of forces of nature and how they act towards human beings if they are well taken care of. Man erects a befitting house referred to as "shrine" for them separated from that of the living beings. Because of this exalted position they occupy among the traditionalists, their abodes are mostly decorated with symbols, patterns, images etc, as these emblems are religiously believed to be alive and living [1].

Africans, most especially the black people who still adhere to African religions, believe in the hierarchy of spirit forces. First, there is God, who is seen to be "in and behind... objects and phenomena... they manifest Him, they symbolize His being and presence [3].

In most shrine paintings in Yoruba land, there are always fear-laden emotions created with images, symbols and "irritating" colour combinations all pointing to the mystical nature of the total rendition. [5] is of the view that these motifs and colours are so much dominated by an intense emotionality and fear; the same motivation that covers the art of the Maoris of New Zealand, the Eskimos and the North-west coast Indians, whereby their art works are in abstract and fearinspiring, as it is in shrine paintings of the Yoruba of south-western Nigeria, [6] discusses a mask whose grotesque features tend to suggest anguish or terror to western viewers, but mockery and derision to Africans. To this end therefore, the totality of the creative activity of the shrine painters has what could be referred to as the "integrated package of characteristics, with conceptualized phenomena." The symbols, motifs and patterns all combine to form the extension of religious imagery with metaphysical embodiment, which the society honour and embrace. 
It is the belief of most traditionalists that the role played by the divinities and the ancestral spirits in the society is great, and in appreciating this, they begin to transform motifs on the walls of shrines using mythical stories and legends to guide their creative ingenuity.

Visits to shrines in Isale-Ora area of Ogbomoso, a town in Oyo State of Nigeria, Osogbo and Ikire, in Osun State of Nigeria, clearly brought to light the concept of linear draughtsmanship of the shrine painters. The various linear art works found in these shrines focused on the religious, cultural and social tendencies. It was discovered that the humanistic experiences of these painters revealed that they use their art of painting to defend or humanize the society. In all these areas, linear art culture has resulted from creative acknowledgment of age-old tradition, which some painters use as inspiration. This artistic linearity of the shrine painters have been religiously accepted as the norm in the society. In spite of the creative successes already achieved by these painters, in the areas of study, they continue to develop through relentless experimentation that also attracts international audience thus; the concept of tourism is created. This concept will eventually help the total wellbeing of the society culturally and economically; as many people will begin to visit shrine centers from far places. The society will be exposed to the outside world and the area will likewise develop structurally.

\section{Motifs}

Shrine painters who are mainly old women are very individualistic in their creation. [7] In his submission as regard images, patterns and symbols in the socalled "Primitive art", attests to it that the total artistic representations are fearinspired. He even categorized the term "Primitive" into two folds, thus we have total "Primitives" and Modern "Primitives"; and that "the West African Negro... does not make a distinction between reality and unreality, [5] also speculates on the degree of fear that is always embedded and evoked in some African works of art which portray mysterious elements, and the fear of the forces of nature.

Shrine painters in various societies in the study area have gone through formalistic development with conventional drawing materials like chalk, brush, felt pen, crayon among others. With these materials they are able to create drawings with unprecedented linear energies to further elevate the level of draughtsmanship in traditional as well as neo-traditional Nigerian art form. Most shrine paintings are characterized by symbolic motifs, patterns and colours. Animals such as lizards, snakes, chameleon, tortoise, birds and schematic lines of different thicknesses and shapes are used in the beautification process. All these animal motifs and colours have meanings, which could be traced in certain myths to the deities referred to as Orisa among the Yoruba.

In most shrines visited, the painters always combine designs and colours to produce soul-inspiring work of divine creativity. Animal motifs are apparent because they have from the earliest times been favourite motifs in Yoruba visual and verbal arts. Notable and common animals in used are tortoise, alabahun; birds, (egret) eye; snake, ejo; etc; they are animals that are equally paramount in 
their folktales and folklores. In combination with the age-old tradition of the Yoruba community, tortoise is being used to elevate and to symbolically portray the deities' ability to excel.

Much of the so-called Yoruba art, generally, was and is still being created as a direct response to strong feelings, the action of the inner forces in man, which is unrelated to conscious thought. These inner forces are interpreted on shrine walls with compelling directness and simple spiritual beauty. Birds are equally in use. Bird is associated with witchcraft, and it is termed the instrument for the witches in traditional belief $[6,8]$ discusses the relevance of bird in Yoruba art and submits that it is wholly related to the powerful women-folk, the witches 'aje'. Bird is used to attract spiritual forces into the shrines, it also helps to intensify and focus devotions by the witches. It involvement in patterning shrine walls makes the shrine efficacious.

Another important animal used in shrine decoration is snake or serpent, ejo, which is usually depicted zig-zag and linear. Snake commonly occurs in the visual arts and oral traditions of numerous peoples in black Africa. Snake plays important role in their cosmology and in the mythical origins of many clans [1]. Generally, animal motif was apparent in "Primitive" man's art in early history and because of this association; it has become very difficult to part with.

The Fulani, found in the west, north, east and central Africa also choose from their common symbols such as the sun, the moon, chevrons, geometric shapes, and stylized patterns. Some of these patterns also appear in Yoruba shrine walls. They are mostly guided by the accumulation of ideas about the universe, the ideas such as procreation and death, agonies of the body and mind, the emotion of joy, fear and love etc. [3]. He further adds that obviously, many ideas about the world have emerged among African peoples, with the conclusion that these views are expressed in myths, legends, symbols etc. [3].

Among the Yoruba, religious ideas have created many of these images, patterns and symbols and in turn these motifs themselves help to communicate and strengthen the religious ideas. These motifs, according to [1] in [9] link up with the energy in the desired objects. In like vein, wall patterning of the Yoruba resembles Ostrich eggshell decoration of the Bushmen in Ghanzi district in Botswana. The decoration is usually linear but with religious undertone as among the Yoruba. Their caves did not provide them with casual shelter alone but almost certainly provided a ritual focus probably for initiation rites or other ceremonies $[10,11]$ explains these paintings in terms of mythological traditions of the individuals, the same way Yoruba shrine paintings are explained and analyzed. The choice of images, symbols and other patterns reflects a passionate care with which the shrine painters work out their relationship with nature, gods and the universe.

\section{Colour symbolism}

It is not an overstatement to stress that the earliest known record for the procurement of materials from natural sources falls within the prehistoric times. Prehistorically, man painted with four basic colours, black, dudu; white, 
funfun; red, pupa and yellow, ofeefe. These colours were mixed with animal fats to produce paste-like paints which were rubbed onto rock surfaces to create impressions on cave walls. In like vein, the Yoruba shrine painters collected their materials mainly from natural and immediate environment before the advent of modern technology. The commonest ritual or religious colours are black, red and white [3], which [12] refers to as the Yoruba primary colours.

It is pertinent to note that these "religious colours" signify different things in different countries in black Africa. But, according to [12] they are traditionally used to take care of human needs in the universe through worship of the various gods and goddesses in the land. It is sad to further add that these colours have reduced their religious and ritual significance simply because they are mostly derived from modern sources. They have lost touch with the intensity of the cultural reality they once possessed. Synthetic colours are presently mixed with natural colours thus adulteration has stepped in and the efficacy reduced.

Black, $d u d u$, is derived from the combination of certain leaves with the addition of local charcoal. The shrine painters in Ikire, Ikirun, Ogbomoso and Ile-Ife confirm this. They are colours that attract our ancestors and gods we worship [13]. These leaves are pounded into creamy consistency with local pap, eko which serves as a binding agent. Sometimes too, animal wastes are added to give additional strength and richness of the colour, black [14]. Devil, trickster esu is represented in shrine paintings with its faviourite colour (black); a divinity known for his dubious, tricky, mischievious and wicked character. Black also symbolizes death, iku, sorrow, ibanuje and misfortune, ori buruku in Yoruba belief system using black colour in shrine painting is directly calling the favour of Esu.

Among the Bamileke and Dogon of Mali, the Mbari houses of the Igbo of Nigeria, and among the Yoruba, black is revered. Red, pupa is mostly obtained from the composition of rocks and volcanic remains, Erowo. It is equally gotten from the blood of animals. This colour symbolizes danger, anger, and violence and when used symbolically in shrine painting, it is associated with the god of iron, Ogun and god of thunder, Sango, because of their volatile and temperamental character. Shrine painters use this colour to solicit spiritual favour from these deities. But when used in shrine paintings they signify love and affection towards these deities who are believed to be in control.

White, funfun sometimes called Efun Orisa, white of the gods, is a sacred colour of Olodumare, the creator of heaven and earth, and it is attributed to the arch divinity 'Obatala' the Yoruba god of creativity. He is pure and righteous. For this reason, when used in sacred arts, shrine paintings inclusive, it focuses and intensifies worship. It also attracts spiritual forces with its aesthetic power, and helps to intensify devotions [15]. The spirit of Obatala is believed to be in the shrine when its favourite colour, white is used in decorating shrine walls.

White is prepared from dry egg shells or small snail shells, which are burnt into biscuit state, red hot and allowed to cool and later ground into fine 
powdery form. Sometimes too, wastes of birds are used. All these colours are used symbolically in shrine painting to promote the good name of these religious instruments - the ancestral spirits. When the three basic colours combine in shrine decoration, the visual as well as spiritual satisfaction is attained and a kind of attention is drawn to Yoruba artistic developments in time.

\section{Relevance of shrine and shrine painting in tourism}

Presently, we have series but not elaborate tourist centers in the south-west Nigeria. What we refer to as tourist centers are not fully developed to worldclass status. For example we have many nature-endowed centers that could be improved upon, of which are the Osun Osogbo groove (shrine) at Osogbo; Ikogosi warm spring (where we have both natural warm and cold water from the rocks); and Museums where artefacts and art works are stored. In order to promote tourism in these places, government at all levels must provide adequate funding to put them into world-class status for future and even present generation. In most shrines found in the south-western Nigeria, there exist series of ritual emblems such as, cutlasses, statuettes, mud sculptures (representing deities), and ritual drums used during annual or occasional festivity performed in the shrines. A total reconstruction of the physical nature of these shrines will enhance the social and psychological identity. This will equally promote tourism in the areas of study. In most of the sculptured, moulded or patterned works found in the shrines, the concept of African proportion is very elaborate and identifiable. One encounters all shapes and sizes of figures, symbols and patterns inextricably linked with the deities in the land. All these artefacts will attract tourism in the areas such as Ikire, Osogbo, Ile-Ife, and many other areas in the south-west of Nigeria where traditional religions still exist.

If the artefacts are well placed in improved environment, tourism will develop. By so doing, people will begin to erect structures such as moderate hotels, motels and affordable houses where people could reside during visits. Selling and buying will improve, thus the promotion of economic activities around the shrine area. In like vein, culture of the Yoruba will also be promoted beyond the borders.

Some of the above suggestions are already in place but not well focused and financially supported. But with the corporation of the local people and the government at all levels, tourism will strive to an unprecedented status in southwest Nigeria, using shrines as a canon of development. When something like this is embarked upon or put in place adequately, people from far and wide will show their interest by visiting the shrines so as to acquire more knowledge on what shrines of the Yoruba stand to represent or express.

\section{Conclusion}

From the foregoing, it is clear that shrine painting still survives in south-west Nigeria among those who still cherish traditional religions. Yoruba of the 
study areas, most especially the traditionalists, think about the world they live in terms of "creation; dream, emotion, mythology and rituals", and thy live a happy "Primitive" life in peace with their environment. Yoruba shrine painters paint so as to gain some kind of control over the negatives of life, and to meet their religious and mythical obligations. The adherents of traditional religions make use of these paintings as a vehicle for cultural upliftment; for this reason, they decorate the abode of the spirits with symbols, images, patterns in both two and three dimensional representations.

The traditional society looks forward to receiving from the creator - God through the ancestral spirits who are believed to sojourn in the shrines where harmony is religiously created in the world of mankind. It is a view of this paper that if the adherents bring adequate sacrifices and offerings to the deities during worship in the shrine, their prayers would be answered to favour the society. In like vein, when these shrines are put into proper use and status, they will symbolize powerful invocations and efficacious acts, because the shrine is considered, among the traditionalists, as a slice of heaven brought to earth. And if shrine paintings are well taken care of, and preserved, the concept of tourism would be encouraged and promoted in the society where found. Thus, the economic as well as cultural values would be enhanced.

\section{References}

[1] Parrinder, G. (1954) African Traditional Religious, London: Hutchinson's University Library.

[2] Personal Interview with Madam Mariam Ibironke of Isale-Ora in Ogbomoso (A town in Oyo State of Nigeria) 17 $7^{\text {th }}$ July 2009.

[3] Mbiti, J.S. (1975) Introduction to African Religion. Heinemann Educational Books Ltd. London.

[4] Personal Interview with Humaani Adefioye of Omitoto Line 2, Ilode, IleIfe. $19^{\text {th }}$ September 2009.

[5] Price, S. (1989) Primitive Art in Civilized Places, The University of Chicago Press, Chicago \& London.

[6] Thompson, R.F. (1968) Esthetics in Traditional Africa. Art News 66 (9).

[7] Myer, Piet (1981) Art et religion des lobi Arts Afrique noires no 19: 19-22.

[8] Personal Interview with Madam Rasidat Awoseemo of Iremo Street in IleIfe (a town in Osun State, Nigeria) on the $7^{\text {th }}$ of August 2009.

[9] Sieber, R. and Walker, R.A. (1988) African Art in the Circle of Life. National Museum of African, Smithsonian Lust Press. Washington D.C. and London.

[10] Brain, R. (1960) Art and Society in Africa, London: Longman.

[11] Brantjes, B. (1969). African Rock Art. London.

[12] Aremu, P.S.O. and Ogunsiakan, T.Y. Red, Black and White as Inevitable Currencies in Yoruba traditional Religions; J.N.L.L. No. 4, Unterschelisshem/Munchem, Germany.

[13] Personal Interview with Madam Sinmbiatu Awero at Isale-Oja area, Ikire. $16^{\text {th }}$ February 2010. 
[14] Personal Interview with Madam Eyinade Oyedeji of Isale-Ora Area of Ogbomoso $12^{\text {th }}$ March, 2010.

[15] Personal Interview with Madam Sabiatu Yusuf of Isale-Aro Area in Osogbo (Capital of Osun State in Nigeria) on the $7^{\text {th }}$ of August. 